\title{
Gestão do setor público: estratégia e estrutura para um novo Estado
}

PEREIRA, Luiz Carlos Bresser. Gestão do Setor público: estratégia e estrutura para um novo Estado, em Reforma do Estado e administração pública gerencial, organizadores. PEREIRA, Luiz Carlos Bresser, SPINK, Peter, $7^{a}$. edição, Rio de Janeiro, Editora Fundação Getúlio Vargas, 2006, 316 p.

\section{Jamile Sumaia Serea Kassem *}

Luiz Carlos Bresser Pereira, no livro Reforma do Estado e administração pública gerencial, organizado por ele e por Peter Spink (Fundação Getúlio Vargas, 2006, $7^{\mathrm{a}}$ edição, 316 páginas) especificamente no artigo escrito por ele, Gestão do setor público: estratégia e estrutura para um novo Estado (21-38 p) traz as características da reforma do Estado, uma reforma que propiciará que se estabeleça, no setor público, uma administração gerencial.

Nos primeiros parágrafos ele situa a condição do governo nos anos 90, e o surgimento da, então, denominada reforma do Estado, que é a reforma administrativa. Neste período, ele havia sido escolhido como ministro do governo Fernando Henrique Cardoso (1994), e pela eclosão da crise de endividamento internacional, propôs que a reforma administrativa fosse incluída entre as reformas constitucionais, reforma fiscal, reforma da previdência social e eliminação dos monopólios estatais. Ocorre que, depois de amplamente debatida, a emenda constitucional da reforma (agosto de 1995), seguiu-se um Plano diretor da reforma do aparelho do Estado, cuja proposta básica é transformar a administração pública brasileira, de burocrática, em gerencial.

Com intuito de melhor elucidar o objetivo do governo na reforma do Estado, segue no texto contextualizando o porquê da reforma do Estado ser a questão central (nacional) dos anos 90. Inicialmente, fez a enumera-

* Aluna especial do programa de Mestrado em Direito Negocial da Universidade Estadual de Londrina. UEL.jamilekassem.adv@gmail.com

REVISTA DO DIREITO PÚBLICO, Londrina, v.9, n.1, p.249-252, jan./abr.2014 
ção das premissas neoliberais que estavam por trás da reforma, e os motivos pelos quais elas se tornaram irrealistas. Sendo o primeiro deles a inobservância dos Estados na legitimidade política que o Estado mínimo possui, o segundo a percepção que a idéia de que as falhas do Estado eram necessariamente piores que as falhas do mercado não passava de dogmatismo.

Com isso, chegou à conclusão de que a solução não seria provocar o definhamento do Estado, mas reconstruí-lo, reformá-lo, e que a reforma significa reduzir o Estado, limitar suas funções como produtor de bens e serviços e, em menor extensão, como regulador; mas implicará também ampliar as funções no financiamento de atividades que envolvam externalidades ou direitos humanos básicos na promoção da competitividade internacional das indústrias locais. Muito embora, a reforma do Estado envolva aspectos políticos, econômicos e administrativos, a mais importante é a reforma administrativa, haja vista que os recursos econômicos e políticos são por definição escassos, mas é possível superar parcialmente esta limitação com o uso eficiente pelo Estado, sendo esta a necessidade da função de uma administração pública eficiente.

Salienta que a maior razão para a reforma do Estado é a importância que se têm dado à proteção do patrimônio público contra as ameaças de privatização. Isto vem desde o século XVIII, se estendeu pelo século XIX e passou a ser dominante na segunda metade do século XX. Ao passo que esta preocupação com a proteção dos direitos públicos crescia em todo o mundo, tornou-se cada vez mais claro que era preciso aprimorar a democracia, e que a administração pública burocrática devia ser substituída por uma administração pública gerencial.

Ao conceituar patrimonialismo e burocracia, Bresser destaca que ao contrário do que se tinha nas sociedades pré-capitalistas, e dada a importância do progresso, no século XIX, de uma administração pública burocrática em substituição às formas patrimonialistas de administrar o Estado, quando o Estado ampliou seu papel social e econômico, no século XX, aquela estratégia adotada pela administração pública burocrática se tronou inadequada, uma vez que à nova administração pública não basta ser efeti- 
va em evitar o nepotismo e a corrupção: ela tem que ser eficiente ao prover bens públicos e semipúblicos, que cabe ao Estado diretamente produzir ou indiretamente financiar.

Em seguida, destaca no texto que a administração pública gerencial emergiu na segunda metade deste século, tendo como causa, emitir uma resposta à crise do Estado, pelo modo de enfrentar a crise fiscal, como estratégia para reduzir o custo e tornar mais eficiente a administração dos imensos serviços que cabiam ao Estado e como instrumento de proteção do patrimônio público contra os interesses do rent-seeking ou da corrupção aberta. Faz uma breve comparação entre a administração pública burocrática e a gerencial. E no subtítulo seguinte esclarece que o enfoque gerencial da administração pública emergiu com vigor na Grã-Bretanha e nos EUA depois que conservadores assumiram o poder.

Por conta disso, a administração publica gerencial é frequentemente identificada com as idéias neoliberais, tendo em vista que a primeira fase da reforma, geralmente chamada de gerenciamento diluído, consiste em medidas para reduzir o gasto público e o número de funcionários, como resposta às limitações fiscais, este fato é que gera reações fortes nos servidores públicos, e à acusação de a reforma ser neoliberal.

O neoliberalismo surgiu de uma reação contra a crise fiscal do Estado e por isso passou a ser identificado com cortes nos gastos e com o projeto de reduzir o tamanho do Estado. Entretanto, logo percebeu-se que a administração pública gerencial é superior à burocrática, o que levou diversos governos de diferentes orientações ideológicas a empreenderem reformas administrativas, quase sempre visando a duas metas: a redução de gastos públicos a curto prazo e o aumento da eficiência mediante uma orientação gerencial, a médio prazo.

Cita que as reações políticas à idéia da administração pública gerencial, surgidas na Grã-Bretanha tem origem ideológica, e que um dos cruciais programas que vem sendo adotado pelo governo britânico é o citizen chart, que prega que toda administração pública gerencial tem de considerar o indivíduo, em termos econômico como consumidor, e, em termos político como cidadão. 
Culmina por mencionar acerca da maneira que reforma na estrutura do Estado deve ser feita, descrevendo os quatro setores nos Estados modernos (núcleo estratégico, atividades exclusivas, serviços não-exclusivos e produção de bens e serviços para o mercado). Com isso, conclui-se que o objetivo da reforma é construir um Estado que responda às necessidades de seus cidadãos; um Estado democrático, no qual seja possível aos políticos fiscalizar o desempenho dos burocratas e estes sejam obrigados por lei a lhes prestar contas, e onde os eleitores possam fiscalizar o desempenho dos políticos e estes também sejam obrigados por lei a lhes prestar contas. Para tanto, são essenciais uma reforma política que dê maior legitimidade aos governos, o ajuste fiscal, a privatização, a desregulamentação e uma reforma administrativa que crie os meios de se obter uma boa governança.

Resenha recebida em: 26/11/2013 Aprovado para publicação em: 27/03/2014

Como citar: KASSEM, Jamile Sumaia Serea. Resenha: PEREIRA, Luiz Carlos Bresser. Gestão do Setor público: estratégia e estrutura para um novo Estado, em Reforma do Estado e administração pública gerencial, organizadores. PEREIRA, Luiz Carlos Bresser, SPINK, Peter, $7^{\mathrm{a}}$. edição, Rio de Janeiro, Editora Fundação Getúlio Vargas, 2006, 316 p. Revista do Direito Público. Londrina, v.9, n.1, p.249-252, jan./abr.2014. DOI: 10.5433/1980511X.2014v9n1p249. 